\title{
An Empirical Investigation of Short runs IPO underpricing: Evidence from Dhaka Stock Exchange
}

\author{
Rakibul Islam \\ Lecturer, Department of Finance, \\ Bangladesh University of Business and Technology, \\ Dhaka-1216, Bangladesh
}

\begin{abstract}
This paper investigates empirical existence of theories of IPO underpricing in Bangladesh. The study based on IPO listed at Dhaka Stock Exchange (DSE) from 2003 to 2013 analyses Level of IPO underpricing and its determinants. OLS regression is used to distinguish the relationship between various independent variables with dependent variable-level of underpricing. The result reveals that market capitalization, underwriter's reputation, oversubscription rate, offer size, float, ownership retention and method of issue have significant effect on the level of IPO underpricing, whereas size of the firm and offer timing has very little explanatory power. The significant effect of these variables identifies the presence of signaling theory, agency theory, winners curse theory, anchoring theory and impresario hypothesis in IPO pricing where signaling theory is most prominent one in deciding IPO underpricing in Bangladesh.
\end{abstract}

Keywords: Initial public offering, Underpricing, and Dhaka Stock Exchange.

\section{Introduction}

Initial public offering (IPO) has been considered as popular topic in the field of finance over a decade. It has proved to be an interesting issue having diversified explorative power for explaining different theories in finance literature. It has been well documented and a number of empirical studies found that IPOs are generally underpriced in developed as well as emerging economies (Ritter et al., 1984). An IPO is said to be underpriced if the price rises above the offer price in the immediate after market. IPO underpricing phenomena contradicts efficient market hypothesis where too many rush on security doesn't put it optimum what makes it more dynamic behavioral and analytical approach to study. Different authors and researchers have proved different models for explaining this anomaly.

Most renowned one is information asymmetric theory based model -adverse selection model(Rock1986) supported and extended by Beatty and Ritter-1986, Carter and Manaster (1990) that informed investors are more successful in selecting good IPOs (adverse selection model) and the exante uncertainty produces more underpricing to have greater return deliberately derived for informed investor. Baron (1982) on his moral hazard model and Booth smiths(1986) certification model supported by Titman and Trueman (1986), Megginson and Weiss (1991) and Kumar And Tsetsekosc(1993) reputational capital paradigm and Allen and Faulhabers signaling model (1989) close to model of Griblatt Hwang (1989) and Welch (1989) inspirit of Ibbotsons (1975) and Leyland and Pyle (1977) and Benveniste and Spindt s truthful revelation model (1989) supported by Bevenite and Busaba (1996) and Aggarwal (2003) and Petway and Kaneko (2003) and Robinson and Pengs(2004) agency theory model of IPO and Ellul and Pagano's (2006) after market liquidity suggest consistency of information asymmetry in IPO pricing (underpricing). Another school of thought showed underpricing phenomena from another dimension. They showed its not deliberate rather depends on some irrational behavioral aspects. Shillars (1990) impresario hypothesis and Matthew Dawson (1984) anchoring effect supported by Geoffrey and Swift (2009) identifies behavioral aspect of investor for IPO underpricing. Undoubtedly these two schools of thought for IPO underpricing have conducted enormous research work but still the specific generalized theory is unresolved.

2.1 Asymmetric Information Theory:

\section{Reasons for IPO Underpricing:}

a. Adverse Selection(winners curse) model: Adverse selection model initiated by Rock (1986) identifying informational asymmetry between informed and uninformed investors where uninformed investors knows only unconditional mean value of the IPO and its lead to a lemon problem-uninformed investors end up with bad IPOs. So the issuing firm deliberately underprices the offerings to attract uninformed investors.

b. Moral Hazard Model: Baron (1982) developed a theory assuming an investor banker is more and better informed than the issuer because issuer cannot perform distribution services unlike an underwriter's. Hence, there should be compensation in the form of underpricing in the presence of asymmetric information. 
c. Certification Model: Booth and Smith (1986) developed a theory showing the role of underwriter to certify issue prices to justify different inside information. Later, Carter and Manaster (1990), Titman and Trueman (1986), Kumar and Tsetsekos (1992), Megginson and Weiss(1991) provided support on that model that prestigious underwriters are associated with less risky IPOs and market value of a IPO firm is positively related to the quality of investment banker, thus it is likely to have less underpricing associated with quality underwriter.

d. Signaling Model: Signaling model presented by Allen and Faulhaber (1989), Griblatt and Hwang (1989) and Welch(1989) in spirit of Ibbotson's (1975) conjecture that IPOs are underpriced to "leave a good taste in investor's mouth"so that future underwriting for the same issuing firm can be sold at attractive prices.

e. Truthful Revelation Model: Benveniste and Spindt (1989) developed a theory of underwriting to improve market efficiency of IPO market. The essence of this theory is so much that it generates Book Building Method- a new IPO pricing method in different countries. By revealing true demand for the issue and market condition to the issuer, underwriters can reduce underpricing phenomena since offer price has already been adjusted to market demand lowering the money left in the table.

f. Agency theory of IPO: Robinson and Peng (2004) presented agency theory of IPO based on entrenchment benefit and IPO generated wealth. It is argued that underwriters and investment public act differently in terms of agency implication of IPO. Underwriters prefer to retain to fulfill its obligation for aftermarket price support whereas higher level of ownership for investment public induces the fear of entrenchment among investors.

\subsection{Behavioral views of underpricing:}

a. Anchoring Effect: There was an Anchoring effect (Matthew Dawson-1984) also termed as Cognitive Bias that reveals human tendency to act upon on the basis of one single trait or piece of information (anchor) in making decision. Geoffrey and Swift (2009) identified anchoring effect on IPO. They argued that IPOs are not being underpriced deliberately by issuers or underwriters, but the price rocketing phenomena on issuance are due to investors over reaction.

b. Impressario Hypothesis: Shillar (1990) explained IPO underpricing from the behavioral point of view and termed as impresario hypothesis where impresarios (investment banker) create appearance of excess demand by trading themselves at higher prices, creating impressions that people are waiting in long queue to buy the security.

Ritter (1991) have found an average cumulative matching firm-adjusted negative return of 15.08 percent after 36 months by analyzing 1526 IPOs. In china, Chan et al (2003) found $145 \%$ average initial return from 1992 to 1997 after examining 701 IPOs. Balwilder Singh and RK Mittal (2003) analyzed 500 IPOs from 1992-1996 in India and found underpriced at a level of $96.56 \%$ on an average.

Robinson and Peng (2004) investigation using large sample of 3075 IPOs, issued between January 1988 to December 1999 in US market documents higher pre- IPO owner retention signals that management expects higher future revenue and higher retention indicates higher agency costs associated with entrenchment.

Islam and Ali (2010) analyze the levels of underpricing in initial public offerings (IPOs) and its determinants of Dhaka Stock Exchange (DSE). Regression Analysis showed that offer size and size of the company are positively related to the degree of underpricing. However, firm's age and offer timing have found no significant explanatory relationship to the level of IPO underpricing .

Bansal and Khanna(2012) analyze IPO that listed at Bombay stock exchange given that (April-1999 to Dec-2012) and explain there is a significant difference in the magnitude of level of underpricing of IPOs that priced through book build with those that are priced through the fixed price option. The result also reveals that Firm's age, ownership structure, retail subscriptions \& market capitalization explained the degree of underpricing. These result had significant impact to the retail and institutional investors willing to invest in Indian primary market.

Sohail and Raheman (2009) investigates the relationship between pre- and post-initial public offering (IPO) investor interest and under-pricing of Karachi Stock Exchange (KSE) and found that Initial return of IPO is positively related to the investor interest in Pre-IPO demand to offer ratio. The over-subscribed IPOs earn significantly high initial abnormal returns to investors and underpriced IPOs have high trading value. Other control variables which influence the level of under-pricing in Pakistan includes offer size float, ex-ante uncertainty, firm size, whereas float was identified as a single most influencing variable in determining the under-pricing.

\section{Objective of the Study}

The general objective is to identify existent theories for the level of IPO underpricing in Dhaka Stock Exchange. The specific objectives are to 
* Identify difference between issue price, offer price and immediate market price in Bangladesh over the year.

* Identify the level of IPO underpricing over the years.

* Justify issue specific, firm specific determinants for IPO underpricing.

4.1 Dependent Variable:

IV. Variable Selection

Relevant with the standard methodology, underpricing is calculated as the percentage change from the offer price to the closing price in the secondary market.

Traditional $($ Raw $)$ underpricing $=(($ closing price - offer price $) /$ offer price $)) * 100$

$$
\text { Log underpricing }=\ln (\mathbf{P 1}-\mathrm{P0} / \mathrm{P0}) * 100
$$

Log Underpricing $=\ln$ (closing price/ offer price) is used to determine the level of underpricing and to make standard practice and to avoid heteroskedasticity. Market adjusted returns on securities (MAARO) is calculated by using following procedure:

Firstly, the return on i security is calculated, where $\mathrm{Ri}=(\mathrm{P} 1-\mathrm{P} 0) / \mathrm{P} 0$ in which, $\mathrm{Ri}=$ return on $\mathrm{i}$ security, $\mathrm{P} 1=\mathrm{Price}$ of $\mathrm{i}$ security on first listing day, $\mathrm{P} 0=$ offer price of $\mathrm{i}$ security.

$$
\mathbf{R i}=(\mathbf{P 1}-\mathbf{P 0}) / \mathbf{P 0}
$$

Secondly, Index return on corresponding days is calculated, where $\mathrm{Mi}=(\mathrm{Ii}-\mathrm{I} 0) / \mathrm{I} 0$ in which, $\mathrm{Mi}=$ market return on ith day, $\mathrm{Ii}=$ closing index (DSE index) at listing day, $\mathrm{I} 0=$ closing index (DSE index) at offer day.

$$
\text { Mi }=(\mathbf{I i}-\mathbf{I 0}) / \mathbf{I 0} .
$$

Now security return (raw return) and market return are used to determine the level of market adjusted IPO return for each security for first trading day by using market adjusted abnormal Return model which is as follows:

$$
\text { Maaro }=\{100 *[(1+R i) / 1+M i)-1]\}
$$

This market adjusted underpricing used as dependent variable for regression analysis.

\subsection{Explanatory Variable}

\subsubsection{Size of the firm}

An inverse relation between the uncertainty and risk and the size of the firm has identified by a number of studies (Titman and Wessels 1988, Schultz 1993, Ibbotson et al 1994). The larger the size of the firm, the lower the uncertainty on the value of the firm and around the listing time (Kiymaz 2000, Bhabra and Pettway 2003), since it has better access to capital and necessary resources for profitability and survival (Finkle 1998), followed by reducing the asymmetry of information problem, and eventually lowering the level of underpricing.

\section{H1: There is a negative link between the firm size and the initial underpricing}

4.2.2 Size of the offer

Carter and Manaster (1990) assert that, besides the uncertainty which surrounds the initial public offering, investors consider its size to assess the performance of initial issue. Empirically, several studies reported a negative relationship between offersize and the level of underprincing of initial issues (Ibbotson 1984, Chalk and Peavy 1990 and Clarkson and Merkley 1994).

\section{$H$ 2: There is a negative link between the size of the offer and the initial underpricing 4.2.3 Underwriters Reputation}

Carter and Manaster (1990) argued that reputed underwriters are associated with IPOs with low dispersion in firm value (less ex ante uncertainty). But Titman and Trueman (1986) identified the market value of IPO firm has positive relationship to the quality of auditor and investment banker. Allen and Faulhaber (1989) identified signaling through IPO by deliberate underpricing of high quality firms.

\section{H3: Underwriters reputation has significant effect on IPO underpricing}




\subsubsection{Ownership Retention}

Robinson and Peng (1990) argued that higher IPO ownership retention signals management expectation of higher future revenue and thereby reducing underpricing. Leyland and Pyle (LP) model to signal information given by entrepreneur is:

$$
\text { LPSig }=\alpha+\ln (1-\alpha)
$$

Where $\alpha$ is the proxy of the LP signal of a firm's future cash flow, as a function of $\alpha$, the fraction of ownership retained by the entrepreneurs. Entrepreneur' ownership retention is measured by $\alpha$.

\section{H4: There is a negative link between the ownership retention and the initial underpricing}

\subsubsection{Offer timing}

Balwinder Singh and RK Mittal, (2003) and Taufil Mohd K.N. (2007), Bansal \& Khanna (2012) identified timing of offer as one of the significant determinants in determining underpricing. The more the timing of offer, the more the road show can be initiated therefore greater the underpricing.

\section{H5: There is a positive link between the offer timing and the initial underpricing}

\subsubsection{Over Subscription Rate}

Dawson (1984), Agarwal S, Liu C, Rhee SG, (2008) identified that the pre-IPO investor demand influences the after-market performance of IPOs by creating upward pressure in the first trading day returns and over-subscription ratio is used as indicator to describe the investor demand in pre-IPO market.

H6: There is a positive link between the over subscription rate and the initial underpricing.

\subsubsection{Free float}

The percentage of share available to public excluding private placement and owner's retention suggest the supply side of IPO. Higher the free float of an IPO, higher the supply of that instrument to compensate demand in indentifying price and hence the higher free float percentage will cause less underpricing (Sohail and Nasr 2007).

H7: There is a negative link between free float and the initial underpricing.

\subsubsection{Market Capitalization}

Sohail and Nasr (2007) pursue the significance of the hypothesis of signal advanced by Allen and Faulhaber (1989) and Welch (1989) showing that the market capitalization indicates, very successfully, the value of the listed Financial Company and not financial firms. It has been evident in earlier research that there is a significant positive relationship between the market capitalization and the level of the underpricing of the new issues.

\section{H 8: The scale of underpricing increases with the level of market capitalization during the listing period}

\subsubsection{Method of Issue}

Benvenste and Busaba (1997), Petway and Kaneko (2003), Bansal and Khanna, (2012), argued that there is significant difference in level of magnitude of underpricing in IPOs that priced through book build with those that are priced through the fixed price option.

H9: The scale of underpricing has significant relation to issue mechanism of IPO.

\section{Research Methodology}

The sample of 100 IPOs listed in DSE 2003 to 2013 out of total 105 IPOs is analyzed using linear regressions. Different Variables are selected on the basis of theories and prior empirical analysis to find out which variables are significant in determining the underpricing. Hence, functional form of econometric model is as follows:

$$
\begin{gathered}
\operatorname{LogMaaro}=\alpha_{\mathrm{o}}+\beta_{1} \log (\mathrm{SOF})+\beta_{2} \log (\text { Ofsiz })+\beta_{3} \text { UnRep }+\beta_{4} \operatorname{Lpsig}+\beta_{5}(\text { OFT })+\beta_{6}(\text { OvSub }) \\
+\beta_{7}(\text { Float })+\beta_{8} \log (\text { MCap })+\beta_{9}(\text { MOI })+\mu
\end{gathered}
$$

Where, 
An Empirical Investigation of Short runs IPO underpricing: Evidence from Dhaka Stock Exchange

\begin{tabular}{|l|l|l|l|}
\hline Symbol & Variable & Measure (proxy) & Prior empirical use \\
\hline LogMaaro & IPO underpricing & $\begin{array}{l}\text { Log transformation of Market Adjusted } \\
\text { Abnormal Return }\end{array}$ & $\begin{array}{l}\text { Sohail and Nasr(2007),Bansal \& Khanna } \\
(2012)\end{array}$ \\
\hline $\log$ (SOF) & Size of Firm & Ln( Net Asset Value of Listing Year) & $\begin{array}{l}\text { Khurshid, Mudambi and Georgen (1999), } \\
\text { Islam, Ali \& Ahmad (2010) }\end{array}$ \\
\hline Ofsiz & Offer Size & $\begin{array}{l}\text { Ln(No. of Share offered multiplied by Offer } \\
\text { Price) }\end{array}$ & $\begin{array}{l}\text { Beatty and Ritter(1986), Ibbotson(1984), } \\
\text { Kaneko and Pettway (2003) }\end{array}$ \\
\hline UnRep & $\begin{array}{l}\text { Underwriters } \\
\text { Reputation }\end{array}$ & $\begin{array}{l}\text { Square Root of no. of IPOs underwritten by } \\
\text { underwriter }\end{array}$ & Carter and Manster (1990) \\
\hline Lpsig & Ownership Retention & $\begin{array}{l}\text { Percentage of Share retained by } \\
\text { Entrepreneurs. }\end{array}$ & $\begin{array}{l}\text { Leyland and Pyle (1977), Grinblatt and } \\
\text { Hwang (1989) }\end{array}$ \\
\hline OFT & Offer Timing & $\begin{array}{l}\text { Time difference from offer date to listing } \\
\text { date(in days) }\end{array}$ & Islam, Ali \& Ahmad (2010) \\
\hline OvSub & Over Subscription Rate & $\begin{array}{l}\text { Amount of subscription over offer size in } \\
\text { percentage }\end{array}$ & Singh and Kumar (2008) \\
\hline Float & Free Float & $\begin{array}{l}\text { Percentage of equity share issued for public to } \\
\text { total issued share }\end{array}$ & Sohail and Nasr(2007) \\
\hline log(MCap) & Market Capitalization & $\begin{array}{l}\text { Ln(No.of Share multiplied by closing market } \\
\text { price of listing date) }\end{array}$ & Sohail and Nasr(2007), Bundoo (2007) \\
\hline MOI & Method of Issue & Book building or not & Bansal \& Khanna (2012) \\
\hline
\end{tabular}

\section{Identification of Offer price and face value difference}

There is significant difference in IPO face value and offer price, out of 105 companies 37 IPO issued at premium which is $35.23 \%$.

Table 01: Identification of Offer price and face value difference

\begin{tabular}{|l|c|c|c|c|c|}
\hline & No. of companies & Mean level & Maximum & Minimum & Standard Deviation \\
\hline Premium & 37 & 44.4594 & 150 & 8 & 36.62 \\
\hline Similar & 68 & 0 & 0 & 0 & 0 \\
\hline Discount & 0 & 0 & 0 & 0 & 0 \\
\hline Total & 105 & 15.51 & 150 & 0 & 31.06467 \\
\hline
\end{tabular}

VII. Identification of Level of underpricing or over pricing

This section presents the level of underpricing and overpricing in the Dhaka Stock Exchange. Table 02 presents the overall levels of IPO underpricing and overpricing at the DSE. It shows that the overall level of underpricing at the Dhaka Stock Exchange was $263.90 \%$ with a standard deviation of 288.37 . There were 100 $(95.25 \%)$ IPOs underpriced and only $5(4.7 \%)$ were overpriced.

Table 02: Identification of Level of underpricing or over pricing

\begin{tabular}{|l|c|c|c|c|c|}
\hline & $\begin{array}{l}\text { No. of } \\
\text { companies }\end{array}$ & Mean level & Maximum & Minimum & Standard Deviation \\
\hline Underpricing & 100 & 263.90 & 1531 & 1 & 288.373551 \\
\hline Overpricing & 5 & 20.133 & 40.75 & 0.416 & 19.71 \\
\hline Similar pricing & 0 & 0 & 0 & 0 & 0 \\
\hline Total & 105 & 250.3823 & 1531 & 0.416 & 287.87 \\
\hline
\end{tabular}

\section{IPO underpricing on yearly basis}

This section identifies raw level of IPO underpricing and Market adjusted IPO underpricing on yearly basis.

The highest degree of underpricing was registered in the year $2010(558.69 \%$ with a standard deviation of 468.19). However there were five companies listed in that year. The next highest level of underpricing was recorded in the year 2009 (456.12\% with a standard deviation of 351.92).There were 11 companies listed with DSE in this year. The 3rd highest level of IPO underpricing at DSE was recorded in the year $2008(352.44 \%$ with a standard deviation of 304.04). There were 10 companies listed in this year.

Table 03: Yearwise Raw IPO underpricing

\begin{tabular}{|r|r|r|r|r|r|}
\hline Year & No. of Companies & Mean level & Maximum & Minimum & Standard Deviation \\
\hline 1995 & 18 & 296.33 & 3860 & 9.83 & 893.57 \\
\hline 1996 & 20 & 267.81 & 1189.75 & 0.64 & 351.34 \\
\hline 1997 & 8 & 60.45 & 102 & 5 & 36.93 \\
\hline 1998 & 4 & 8.07 & 23.73 & 0.86 & 10.53 \\
\hline 1999 & 9 & 46.69 & 102.25 & 11.5 & 30.82 \\
\hline 2000 & 4 & 38.95 & 68 & 20 & 22.21 \\
\hline 2001 & 11 & 175.55 & 1320 & 9 & 384.35 \\
\hline 2002 & 6 & 72.75 & 161 & 8 & 57.99 \\
\hline 2003 & 9 & 61.12 & 124.5 & 1 & 47.85 \\
\hline
\end{tabular}




\begin{tabular}{|r|r|r|r|r|r|}
\hline 2004 & 2 & 303 & 405 & 200 & 145.31 \\
\hline 2005 & 12 & 240.67 & 600 & 30 & 197.49 \\
\hline 2006 & 9 & 154.34 & 353.5 & 13.5 & 120.59 \\
\hline 2007 & 12 & 189.238 & 466.16 & 24 & 128.18 \\
\hline 2008 & 10 & 352.44 & 829 & 48.75 & 304.04 \\
\hline 2009 & 11 & 456.12 & 1527.5 & 153.29 & 351.92 \\
\hline 2010 & 5 & 558.69 & 1262 & 135.75 & 468.19 \\
\hline 2011 & 7 & 215.52 & 640 & 21.33 & 274.08 \\
\hline 2012 & 8 & 287.89 & 1531 & 4 & 512.88 \\
\hline 2013 & 15 & 235.97 & 721 & 25.33 & 119.20 \\
\hline
\end{tabular}

Source: This is an updated version of Table 6 of Islam, Ali \& Ahmad (2010).

In terms of market adjusted underpricing, the highest degree of underpricing was registered in the year 2010 (486.546\% with a standard deviation of 386.63). The next highest level of underpricing was recorded in the year 2009 (400.627\% with a standard deviation of 307.27). The 3rd highest level of IPO underpricing at DSE was recorded in the year 2008 (367.965\% with a standard deviation of 324.18). The $4^{\text {th }}$ highest level of IPO underpricing at DSE was recorded in the year 2012 (273.258\% with a standard deviation of 469.825).

Table 04: Year wise Market Adjusted IPO underpricing

\begin{tabular}{|r|r|r|}
\hline Year & Mean level & Standard Deviation \\
\hline 2003 & 44.69 & 33.96 \\
\hline 2004 & 147.45 & 178.49 \\
\hline 2005 & 67.01 & 99.79 \\
\hline 2006 & 138.03 & 113.70 \\
\hline 2007 & 151.10 & 111.16 \\
\hline 2008 & 367.97 & 324.18 \\
\hline 2009 & 400.63 & 307.27 \\
\hline 2010 & 486.55 & 386.63 \\
\hline 2011 & 249.58 & 302.83 \\
\hline 2012 & 273.26 & 469.83 \\
\hline 2013 & 213.03 & 206.57 \\
\hline
\end{tabular}

Above Figure 01 indicate the association of raw level of underpricing and market adjusted underpricing from 2003 to 2013 in DSE. It is evident here that market adjusted underpricing and raw underpricing have followed on average a same directional patern. A rise in level of underpricing from 2007 to 2010 followed by a radical fall in 201 lidentifies the IPO market volatility in Bangladesh. In both cages of raw and market adjusted underpricing, 2010 registered as the most underpriced IPO year.

Figure 01: Year wise underpricing- Raw Vs Market Adjusted

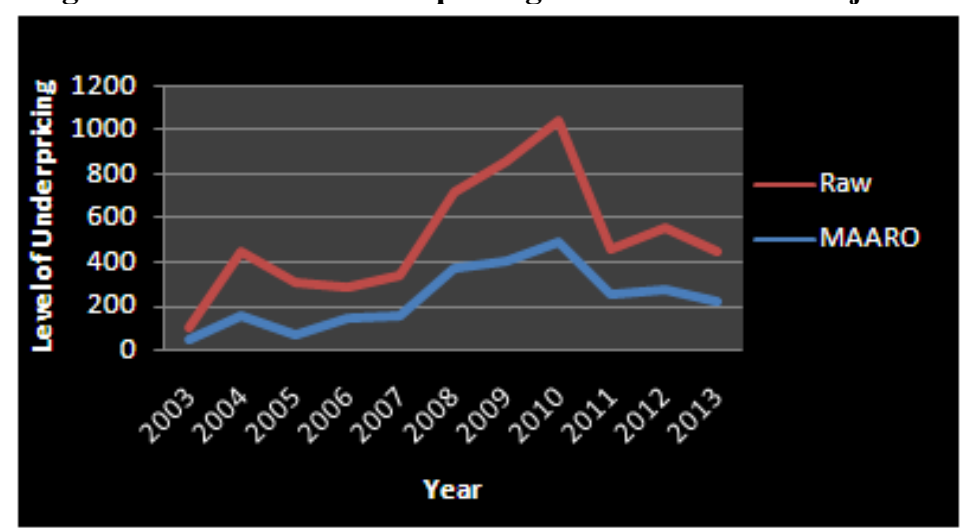

\section{Result Of Cross sectional regression analysis}

Ordinary least square (OLS) regression used to explain the cross-sectional variation in the abnormal returns. Table below, provides the result of regression model. The results obtained by running regression analysis on SPSS and STATA are similar to each other. 


\begin{tabular}{ll|l|l}
\hline source & SS & df & MS \\
\hline Model & 14.7390 & 9 & 1.6376 \\
Residual & 13.1913 & 90 & .14657 \\
Total & 27.9303 & 99 & .2821 \\
\hline
\end{tabular}

$\begin{array}{rll}\text { No. of obs } & = & 100 \\ \text { F (9, 90) } & = & 11.17 \\ \text { Prob }>\text { F } & = & 0.000 \\ \text { R-squared } & = & 0.5277 \\ \text { Adj R-squared } & = & 0.4805 \\ \text { Root MSE } & = & .38284\end{array}$

\begin{tabular}{l|ccclrr}
\hline LogMaaro & Coef. & Std.Err & t & P > I t I & \multicolumn{1}{c}{ [95\% Conf. Interval] } \\
\hline $\log$ (SOF) & .0590 & .0433 & 1.36 & 0.177 & -.0272 & .1452 \\
Ofsiz & -.1473 & .0577 & -2.55 & $0.012 * *$ & -.2619 & -.0328 \\
UnRep & .1013 & .0316 & 3.20 & $0.002 *$ & .0385 & .1641 \\
Lpsig & -.1962 & .0932 & -2.10 & $0.038 * *$ & -.3814 & -.0109 \\
OFT & .0004 & .0003 & 1.37 & 0.174 & -.0002 & .0010 \\
OvSub & .0099 & .0033 & 3.01 & $0.003 *$ & .0034 & .0165 \\
Float & -.9775 & .4577 & -2.14 & $0.035 * *$ & -1.8868 & -.0682 \\
log(MCap) & .2240 & .0497 & 4.51 & $0.000^{*}$ & .1253 & .3227 \\
MOI & .3933 & .2258 & 1.74 & $0.085^{* * *}$ & -.0553 & .8420 \\
cons & 4.3720 & .7969 & 5.49 & 0.000 & 2.7889 & 5.9550 \\
\hline
\end{tabular}

$*$ Significant at $1 \%$ level, ${ }^{* *}$ Significant at $5 \%$ level, ${ }^{* * * \text { Significant at } 10 \% \text { level }}$

The regression models' result suggests that $\log ($ Mcap) has positive and highly significant (at $1 \%$ level of significance) relation to IPO underpricing. This result confirms earlier empirical analysis by Bundoo (2007), Sohail and Raheman (2009). This result is pertinent to signaling theories by Allen and Faulhaber (1989) and Welch (1989) indicating larger firm in terms of market value have good signaling effect in the market. Therefore scale of underpricing increases with the level of market capitalization. Hence, null hypothesis 8 can be rejected.

Another important finding provided by regression result is the positive and highly significant (at $\mathbf{1 \%}$ level of significance) relationship between UnRep and the level of underpricing. The result contradicts the finding of Carter and Manaster (1990), as more the IPO underwritten by reputed quality underwriter, more it tend to be low risk IPO, thus less would be underpricing. But since quality underwriters convey positive information to the market, the tendency to rise the immediate after market share price rises pertinent to the quality of underwriter. So the gap between offer price and immediate market price is enlarged for the high quality or highly reputed underwriter increasing the level of underpricing. Another way of explation is that high quality firms deliberately set low price to derive benefit from subsequent offerinfgs (Allen and Faulhaber-1989). So the null hypothesis 3 cannot be accepted.

The result of regression model also suggests that there is a positive and highly significant (at $1 \%$ level of significance) relationship between OvSub and the level of underpricing. Over subscription rate indicates the demand side of the pre-IPO market. So alternative hypothesis made on that ground are satisfied by empirical analysis which is consistent with findings of Rock 1986, Agarwal S (2008), Sohail and Raheman (2009). Hence null hypothesis 6 can be rejected.

The model also found that there is a positive relationship between $\mathbf{O f s i z}$ and level of underpricing. Here $\mathrm{P}$ value is .012 suggesting highly significant relationships at $5 \%$ level of significance that is consistent with the findings of Beatty and Ritter(1986), Ibbotson(1984), Kaneko and Pettway (2003), Islam, Ali \& Ahmad (2010). Hence null hypothesis 2 can be rejected.

From table, the result of variable Float shows that there is negative and significant (at $5 \%$ level of significance) relationship between Free Float and underpricing. So it has been proved that as long as supply can offset the demand for IPO there is low level of underpricing that is the initial abnormal return should remain at lower level. Hence null hypothesis 7 cannot be accepted.

Above table also identifies a significant negative relationship between Lpsig and level of underpricing (at 5\% level of significance). The ownership retained by entrepreneurs signals management and owners expectation for greater future prospect of the firm. And this confidence reduces the level of underpricing which is consistent with the findings of Grinblatt and Hwang (1989), Robinson and Peng (2004). Therefore, null hypothesis 4 cannot be accepted.

The model also found that there is a positive relationship between MOI and level of underpricing. Here $\mathrm{P}$ value is .085 suggesting significant relationships at $10 \%$ level of significance. This result is consistent with the empirical findings of Petway and Kaneko (2003). So, null hypothesis 9 cannot be accepted.

Here $\log (\mathbf{S O F})$ (size of firm) and OFT (offer timing) have no significant effect on the level of underpricing. Therefore hypothesis 1 and 9 are not substantiated.

The adjusted $\mathrm{R}$ square is $48.05 \%$. This means that size of the firm, offer size, underwriters reputation, ownership retention, offer timing, over subscription rate , free float, market capitalization and method of issuebook building process can explain $48.05 \%$ variations of the degree of underpricing at the Dhaka Stock 
Exchange. This indicates that there are other factors that may explain $51.95 \%$ variations of the degree of underpricing at the Dhaka Stock Exchange. The Durbin-Watson falls within the range of acceptability (1.57). Therefore there was no serial correlation problem in the data. The VIF $(1-10)$, tolerance $(0.1-1)$ fall into the range of acceptability. So there was no serious multicolleniarity problem in the regression model. Histogram suggests the normality of the data. Normality test also suggest that variable extracted from the sample follows normal distribution. Normal P-P plot shows that the data were linear. The test for heteroscedasticity (BreuschPagan / Cook-Weisberg test for heteroskedasticity) that is whether the variance from disturbance term for each explanatory variable is statistically same (homo) or not (hetero) is conducted. The chi square value of 14.17 suggesting null hypothesis of constant variance cannot be rejected because $\mathrm{p}>$ chi at $11.66 \%$. The F-value is high (11.17) and found to be significant at $1 \%$ significance level ( $\mathrm{Sig} F=.000$ ). All these identify the robustness of the model and now it can be said an adequate model.

\section{Conclusion}

This paper attempts to design for and test empirical models which integrate company specific and issue specific factors to explain IPO underpricing in DSE from 2003 to 2013. The paper identifies the offer price and face value difference, level of under and overpricing, the level of underpricing on yearly basis. Multiple linear regressions are used to distinguish the relationship between various independent variables with the dependent variable. The independent variables are Size of the firm (net asset value), Offer size, Underwriters Reputation, Ownership Retention, Offer timing, Over subscription rate, Freefloat, Market Capitalization and Method of the issue-book building process to explain dependent variable-the level of underpricing.

Out of the 105 companies that were listed in the years 2003 to 2013, 100 (95.25\%) IPOs were found to be underpriced and $5(4.7 \%)$ were overpriced .The overall level of overpricing was $20.133 \%$ with a standard deviation of 19.71. The IPOs of DSE was largely underpriced at 263.90percent with a standard deviation of 288.37. These are consistent with earlier findings of Hoque and Musa (2002), Islam M.S. (1999) and Islam and Ali \& Ahmad (2010).

Using a regression approach, the degree of underpricing is explained by asymmetric information theory and behavioral theories of IPO pricing. It is found that other than size of the firm and offer timing all variables included in regression function have significant effect on under pricing. In particular, the results showed that Underwriters reputation, Market capitalization have highly significant positive effect on IPO underpricing and Ownership retention have a negative effect on IPO underpricing. These results convey the prevailing signaling hypothesis of Ibbotson (1975), Allen and Faulhabers (1989), Grinblatt Hwang (1989) in the market of initial issue. The result pertaining to underwriter's reputation also explains the agency theory of IPO pricing (Robinson and Peng 2004).There is a significant positive relation found between oversubscription rate and IPO underpricing and a significant negative relation found between offer size and IPO underpring. These results explain the empirical existence of the hypothesis of winners curse model (Rock 1986, Beatty and Ritter 1986). The general demand supply theory is found relevant in initial issue market since free float has a negative and over subscription rate has positive relation to IPO underpricing. The result of oversubscription rate can be explained by anchoring effect of IPO pricing (Dawson 1984). Here, Method of issue plays a significant role in deciding IPO underpricing. The positive relation found between method of issue following book building procedure and IPO underpricing may be controversial but this result found in Bangladesh is similar to the result found in Japan (Pettway and Kaneko 2003). One explanation for this positive relationship may be impresario hypothesis (Shillar 1990) where fake impression made by inter-underwriters bidding makes the initial price run ups for new issue securities. So a major revision for book building procedure is required to impound market demand properly and have a more control over the inside information utilized by investment banker so that the level of underpricing can be reduced and more fund can be channeled for industrialization .

This is only a short run IPO performance analysis and covers the most recent time period 2003 to 2013. Nonetheless, the limitations of this study can open the opportunity for further research work in this field. Overall result can be improved by adding more factors and observations into the study. But the thing is that there is no research been conducted all these variable altogether covering the time period like this paper prior to this study.

\section{Appendix:}

a. Colinearity Analysis

\begin{tabular}{l|ll} 
Variable & VIF & 1/VIF \\
\hline $\log ($ MCap) & 3.59 & 0.278552 \\
Ofsiz & 3.39 & 0.294985 \\
Lpsig & 1.46 & 0.684932 \\
Float & 1.39 & 0.719424 \\
MOI & 1.34 & 0.746269 \\
UnRep & 1.22 & 0.819672 \\
OFT & 1.16 & 0.862069
\end{tabular}




\begin{tabular}{l|ll} 
OvSub & 1.15 & 0.869565 \\
$\log (\mathrm{SOF})$ & 1.07 & 0.934579 \\
\hline Mean & 1.75 &
\end{tabular}

b. Dependent Variable : Logmaaro

Residuals Statistics (*)

\begin{tabular}{|l|r|r|r|r|r|}
\hline & \multicolumn{1}{|c|}{ Minimum } & \multicolumn{1}{c|}{ Maximum } & \multicolumn{1}{c|}{ Mean } & Std. Deviation & \multicolumn{1}{c|}{ N } \\
\hline Predicted Value & 5.8542 & 7.9293 & 6.9422 & .37830 & 100 \\
Residual & -.91093 & .97100 & .00000 & .37285 & 100 \\
Std. Predicted Value & -2.876 & 2.609 & .000 & 1.000 & 100 \\
Std. Residual & -2.329 & 2.483 & .000 & .953 & 100 \\
\hline
\end{tabular}

* Dependent Variable: Logmaaro

Histogram

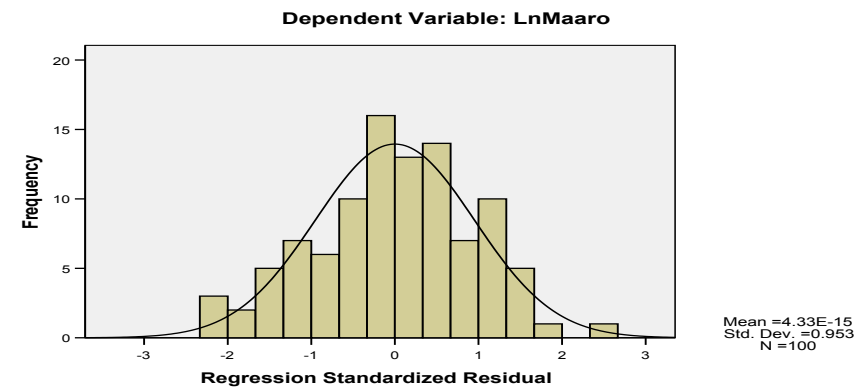

c. Linearity Test

Normal P-P Plot of Regression Standardized Residual

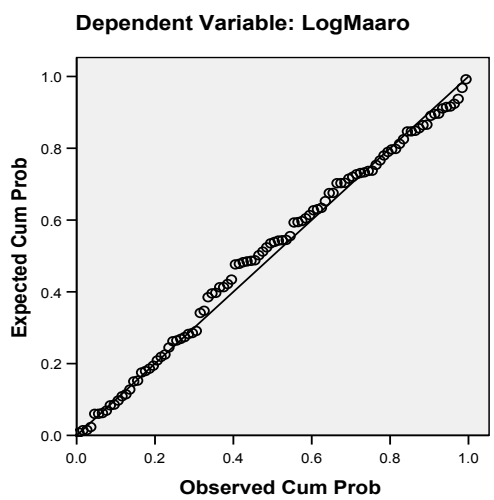

d. Normality Test

Anderson-Darling test (Residuals)

\begin{tabular}{lr}
\hline $\mathrm{A}^{2}$ & 0.383 \\
$\mathrm{p}$-value & 0.391 \\
alpha & 0.01 \\
\hline
\end{tabular}

Test interpretation:

H0: The variable from which the sample was extracted follows a Normal distribution.

Ha: The variable from which the sample was extracted does not follow a Normal distribution.

As the computed $p$-value is greater than the significance level alpha $=0.01$, one cannot reject the null hypothesis $\mathrm{H} 0$.

The risk to reject the null hypothesis $\mathrm{H} 0$ while it is true is $39.11 \%$.

Jarque-Beta test

(Residuals):

\begin{tabular}{lr}
\hline JB (Observed & 1.4 \\
value) & 80 \\
JB (Critical & 9.2
\end{tabular}




\begin{tabular}{lr} 
value) & 10 \\
DF & 2 \\
& 0.4 \\
p-value & 77 \\
& 0.0 \\
alpha & 1 \\
\hline
\end{tabular}

Test interpretation:

H0: The variable from which the sample was extracted follows a Normal distribution.

Ha: The variable from which the sample was extracted does not follow a

Normal distribution.

As the computed $p$-value is greater than the significance level alpha $=0.01$, one

cannot reject the null hypothesis $\mathrm{H} 0$.

The risk to reject the null hypothesis $\mathrm{H} 0$ while it is true is $47.72 \%$.

\section{Breusch-Pagan / Cook-Weisberg test for heteroskedasticity}

Ho: Constant variance

Variables: lnnav underep ownret offtim ovsub flt lnos lnmc bb

$$
\begin{array}{ccc}
\operatorname{chi} 2(9) & = & 14.17 \\
\text { Prob }>\text { chi2 } & = & 0.1166
\end{array}
$$

\section{Reference}

[1]. Agarwal, S., C. Liu and S.G. Rhee (2008), "Investor demand for IPOs and aftermarket performance: Evidence from the Hong Kong stock market”, Journal of International Financial Markets, Institutions and Money, Vol 18 No2 pp 176-19.

[2]. Aggarwal, Reena. (2003), “Allocation of initial public offerings and flipping activity”, Journal of Financial Economics , Vol 68 no 1 pp111-135.

[3]. Aggarwal, Reena; Rivoli, Pietra. (1990), "Fads in the initial public offering market?” Financial Management, Winter 90, Vol. 19 Issue 4, pp 45-47.

[4]. Allen, Franklin, and Gerald R. Faulhaber, (1989). "Signaling by Underpricing in the IPO Market", Journal of Financial Economics, vol 23, pp 303-323.

[5]. Balwinder Singh and PK Mittal, (2003), "Underpricing of IPOs: Indian Experience", The ICFAI Journal of Applied Finance, 9(2), p.29.

[6]. Bansal, R., and Khanna, A., (2012), "IPOs Underpricing and money left on the table in indian market", International Journal of Research in Management, Economics and Commerce,Vol2, Issue 6(June 2012), pp106-120

[7]. Baron, David P.,(1982), "A Model of the Demand for Investment Banking Advising and Distribution Services for New Issues", Journal of Finance 37, 955-976.

[8]. Beatty R. and Ritter J., (1986), "Investment Banking, Reputation, and the Under-pricing of Initial Public Offerings", Journal of Financial Economics 15, p. 213-232

[9]. Benveniste, Lawrence M., and Paul A. Spindt, (1989), "How investment bankers determine the offer price and allocation of new issues", Journal of Financial Economics 24, 343- 361

[10]. Benvenniste L.M., W Y Busaba and W.J. Wilhelm, (1996), "Price Stabilization as a bonding Mechanism in new equity issues", Journal of financial Economics, Vol 42 no 2 pp223-255

[11]. Bhabra, H. S. and R. H. Pettway (2003), "IPO prospectus information and subsequent performance", Financial Review, (38): 369-397.

[12]. Booth.J. and R. Smith. (1986), "Capital Raising, Underwriting and the Certification Hypothesis, Journal of Financial Economics", 15,pp261-281

[13]. Bundoo, S.K., (2007), “An Analysis of IPOs Underpricing in Mauritius”, African Journal of Accounting, Economics, Finance and Banking Research, Vol.1.No.1.pp1-11

[14]. Carter R. and S. Manaster (1990), "Initial public offerings and underwriter reputation", Journal of Finance", 45: 1045-1068

[15]. Chalk A.J. and J.W. Peavy (1987), "Initial Public Offerings: Daily Returns, Offering Types and the Price Effect", Financial Analysts Journal, 43: 65-69

[16]. Chan, K., J. Wang, and K. C. J. Wei, (2003). "Underpricing and long-termperformance of IPOs in China", Journal of Applied Corporate Finance, 1-22

[17]. Clarkson, P. M. and J. Merkley (1994), "Ex Ante Uncertainty and the Underpricing of Initial Public Offerings: Further Canadian Evidence", Canadian Journal of Administrative Sciences, II(1): 54-67

[18]. Dawson, S.M. (1984), “Overbidding for New Share Issues”, Singapore Stock Exchange Journal of Finance, pp. 14 -2 7.

[19]. Ellul and Pagano, (2006), "IPO underpricing and After- Market Liquidity, Society for Financial Studies", The review of Financial Studies, vol 19, issue 2 pp381-421

[20]. Finkle, T.A. (1998), "The relationship between boards of directors and initial public offerings in the biotechnology industry", Entrepreneurship Theory and Practice, 22: 5-29.

[21]. Geoffrey C., and C. Swift, (2009), "Overreaction in the thrift IPO aftermarket", Journal of Banking \& Finance 33(7), pp. 12851298. Available at http://digitalcommons.unl.edu/financefacpub/5/.

[22]. Grinblatt, Mark, and Chuan Yang Hwang, (1989). "Signaling and the Pricing of New Issues", Journal of Finance, 44, 393-420.

[23]. Ibbotson, R. G., J. Sindelar, and J. Ritter (1994), "The market's problems with the pricing of initial public offerings", Journal of Applied Corporate Finance, 7: 66-74.

[24]. Ibbotson, R., (1975), "Price performance of common stock new issues", Journal of Financial Economics, Vol. 2, pp. 235-272.

[25]. Islam MA, Ali R, Ahmad Z, (2010). "An empirical investigation of the under-pricing of initial public offerings in the Chittagong Stock Exchange", International Journal of Economics and Finance, 2(4): 36-46. 
[26]. Islam,A. and ali, R. (2010), "Underpricing of IPOs: The case of Bangladesh”, Global Economy and Finance Journal, Vol.3 No.1, pp. 44-61.

[27]. Jain, B. A. and O. Kini (2000), “Does the presence of venture capitalists improve the survival profile of IPO firms?" Journal of Business Finance and Accounting, 27: 1139-1176

[28]. Kiymaz, H.,(2000), "The initial and aftermarket performance of IPOs in an emerging market: Evidence from Stock Exchange", Journal of Multinational Financial Management, 2000, vol. 10, pp. 213-227.

[29]. Koneko, T., Petway, R. H., (2003), “Auctions Versus Book Building of Japanese IPOs”, Pacific- Basin Finance Journal, 11, pp439-462.

[30]. Kumar P.C. and Tsetsekos, (1993), “Asymmetric information, Investment Banking Contracts and the Certification Hypothesis", Journal of Banking and Finance, 17(1),pp117-129

[31]. Leyland.H and D. Pyle, (1977), "Informational asymmetries, Financial structure and Financial intermediation", Journal of Finance, vol32, pp 371-387

[32]. Megginson. W.L. and Katheleen A.Weiss. (1991), "Venture capitalist certification in initial public offering", The journal of Finance, 46 pp. 879-903

[33]. Ritter, J.R., (1984), "Signaling and the Evaluation of Unseasoned New Issues: A Comment", The Journal of Finance, 39, 12311237.

[34]. Robinson and Robinson and Peng, (2004), "Underpricing and IPO ownership retention", Journal of Economics and Finance, Vol 28, No 1, pp 132-146

[35]. Rock, K. (1986). "Why New Issue are Under Priced”, Journal of Financial Economics, 15, 187-212.

[36]. Ruud. J.S.1991, Another View of Underpricingof Innitial Public Offering, Federal reserve bank of New York Quaterly Review, 16,pp 83-85

[37]. Schultz, P. (1993), "Unit initial public offerings", Journal of Financial Economics, 34: 199- 229.

[38]. Shillar.R.J. (1990), "Speculative Prices and Popular Models”, Journal of economic Persrective, Vol 4,no 2, pp 55-65

[39]. Singh,P. and B. Kumar, (2008), "Short run and long run dynamics of initial public offering- evidence from India", available at http://ssrn.com/abstruct $=1254060$

[40]. Sohail MK, Raheman A, (2009), "Determinants of under-pricing of IPOs regarding financial \& non-financial firms in Pakistan", European Journal of Economics, Finance and Administrative Sciences, 15: 62-73.

[41]. Sohail, M.K , and Nasr.M. (2007), "Performance of Initial Public Offerings in Pakistan", International Review of Business Research Papers Vol.3 No.2 June 2007, Pp. 420 - 441

[42]. Sohail, M. K. and Raheman, A. (2009), "Determinants of Under Pricing of IPOs Regarding Financial and Non-Financial Firms in Pakistan", European Journal of Economics, Finance and Administrative Sciences, Issue 15, pp.62-73

[43]. Taufil Mohd K.N. (2007), "The long run performance of initial public offerings in Malaysia".Presented inthe MFA 9th Conference, 12-13th June, Kuala Lumpur.

[44]. Titman, S. and R. Wessels (1988), “The determinants of capital structure choice", Journal of Finance, (43): 1-19.

[45]. Titman, S., \& Trueman, B., (1986), "Information Quality and the Valuation of New Issues", Journal of Accounting and Economics 8:159-172

[46]. Welch, Ivo, (1989), "Seasoned Offerings, Imitation Costs, and the Underpricing of Initial Public Offerings", Journal of Finance $44,421-449$. 